Brit. J. prev. soc. Med. (1975), 29, 267-273

\title{
The influence of the birth of a malformed child on the mother's further reproduction
}

\author{
R. G. RECORD AND EILEEN ARMSTRONG \\ Department of Social Medicine, University of Birmingham
}

\begin{abstract}
Record, R. G. and Armstrong, E. (1975). British Journal of Preventive and Social Medicine, 29, 267-273. The influence of the birth of a malformed child on the mother's further reproduction. Births which occurred in Birmingham in 1964-70 were assembled into fraternities by computer linkage. By calculating the frequency with which one birth was followed by another and the interval between births the reproductive behaviour of mothers after the birth of a malformed child was compared with that of all mothers, taking account of differences in maternal age, parity, and period of observation. It was found that malformations which resulted in stillbirth or early death were more frequently followed by another birth and that the interval to the following birth was shorter than usual. In this respect malformations did not differ in their effect from other causes of stillbirth and infant death. The birth of children with severe malformations who survived, however, acted as a slight deterrent to further reproduction. The malformation rate among children born after a malformation was double the usual rate; the recurrence rate was particularly high for neural tube defects, $5 \%$ of subsequent children being affected. In spite of this parents of children with central nervous system malformations were not deterred from further reproduction unless the affected child survived.
\end{abstract}

There have been only a few studies of the attitude of parents with regard to further reproduction after the birth of a malformed child. Specific defects which have been investigated from this point of view include spina bifida (Hare, et al., 1966; Timson, 1970; Walker, Thomas, and Russell, 1971; Richards and McIntosh, 1973; Hunt, 1973), congenital heart disease (Polani and Campbell, 1955; Apley, Barbour, and Westmacott, 1967; Boon, 1972), and Down's disease (Newcombe, 1965). There are also a few references to reproductive behaviour following stillbirths and infant deaths (Newcombe and Rhynas, 1962; Sheps, 1965; Vogel and Knox, 1975) where no attempt was made to distinguish between malformations and other causes of death.

The impression gained by reading these accounts is that the birth of a malformed child may affect the subsequent reproductive behaviour of parents in various ways. Some parents may be so shocked by the event that they may resolve to have no more children in order to avoid any risk of enduring again such a distressing experience. Indeed this course may be urged upon them by genetic counsellors and other advisors in the case of malformations such as neural tube defects where the risk of recurrence may be regarded as unacceptably high. On the other hand some parents may respond by deciding to have another child as quickly as possible to compensate for the disappointment caused by the birth of a defective child. This may be more likely if the malformed child died at or soon after birth. If however the child lives but is severely disabled requiring constant maternal attention the parents may postpone further reproduction for an indefinite period, possibly for ever.

Some of these views are based on parents' stated intentions shortly after the malformed birth and others result from following-up parents for varying periods and noting the number of subsequent children or, in some cases, the total size of the completed family. Interpretation of some of these studies is hampered by the absence of an acceptable control group. There seems to be no record of a comprehensive study of malformed births designed 
to investigate whether further reproduction is influenced by the type of malformation and its outcome in terms of early death or severe handicap. We were therefore prompted to examine the possibility of using the Birmingham malformation register and the associated birth data for this purpose. The present paper describes the method and results of this investigation.

\section{Method}

Data relating to all births to Birmingham residents have been collected continuously since 1950 . In 1964 a reliable means of maternal identification was introduced based on the mother's date of birth, the first two letters of her forename, and the first three letters of her maiden surname. By means of a simple computer linkage operation it was possible to assemble in sequence, data on all births to each woman from the beginning of 1964 to the end of 1970. The method worked well with the records of the indigenous population but immigrants presented some difficulty because some did not know their exact date of birth and some had surnames which were not sufficiently distinctive. It was decided therefore to restrict the analysis to mothers of British, Irish, or European origin. The effect on later reproduction of twins in a fraternity is itself of interest and will be reported on later. Their inclusion here, however, complicates the analysis and it was thought that little error would result from excluding them. The present analysis is, therefore, based on Birmingham women of Caucasion origin who had singleton births in the years 1964-69 followed-up to the end of 1970. The series consists of 69196 mothers and 97467 births, but for 317 births the age or parity of the mother was not known. These were excluded leaving 97150 births of whom 2169 were malformed (22 per 1000).

The successful assembling of fraternities depends on the continued residence within the city of each mother and since about $35 \%$ of children born in 1964 were not traceable at the age of five years it is clear that a number of families had left the city during the follow-up period and some of their subsequent births would not have been recorded. The present study, therefore, understates the reproductive experience of the women in the series. Nevertheless comparison of a special group of women, for example those who had a malformed child, with the whole population of mothers is feasible provided they do not differ from other mothers in their mobility. The methods of measuring reproductive behaviour which we adopted enabled us to investigate this point.
There are several ways of measuring reproductive performance of a group of mothers subsequent to a particular birth. The two simplest measures, and the ones chosen for this study are:

(1) the proportion of women who have a child subsequent to the index birth within a stated period (in this case up to the end of 1970);

(2) for those who have a subsequent birth, the interval from the index birth to the next birth following.

There is particular advantage in using both these measures in a series subject to loss by movement out of the study area. It is possible that families in which a stillbirth or early death occurs are more mobile than those where the child survives, and if a higher proportion than average of these families move out of the area, so that subsequent births do not come to notice, the proportion of mothers for whom a later birth is recorded would be less than for less mobile families. This would give an impression of impaired reproductive performance and such a group of women would be expected to show a longer than average interval before the next birth $\frac{\mathrm{Q}}{\mathrm{D}}$ In fact, because women moving out of the area have a shorter time in which to have their next baby if is to be included in the study the average interva 8 would tend to be less than normal.

If, therefore, a group of women showed a paraco doxical result of fewer subsequent births than usuat and a shorter interval between births, one would suspect undue movement of women out of the series and no conclusion concerning their reproductive performance would be permissible. On the other hand, consistency between the two measures(a) a smaller proportion of mothers having subsequent births and a longer interval before the next birth, or (b) more mothers having later births and a shorter interval-would suggest respectively impaired or enhanced reproductive performance.

In using these measures of reproductive behaviour to compare a particular group of mothers with all mothers, it is necessary to take account of three important variables which are closely related to reproductive performance-age of the mother, the number of previous children, and the duration of follow-up (which depends of course on the year of the index birth). The effect of these variables on the proportion of index births followed by a or later birth is shown in Table I. As would be expected, $N$ the proportion falls with increasing age and with reduction in the duration of follow-up, but the relation to the number of previous births is more complicated. When the simultaneous relationship to all three variables is studied a very complex $\stackrel{?}{?}$ 
TABLE I

PROPORTION OF BIRTHS FOLLOWED BY A LATER BIRTH AND MEAN INTERVAL FROM INDEX BIRTH TO NEXT FOLLOWING

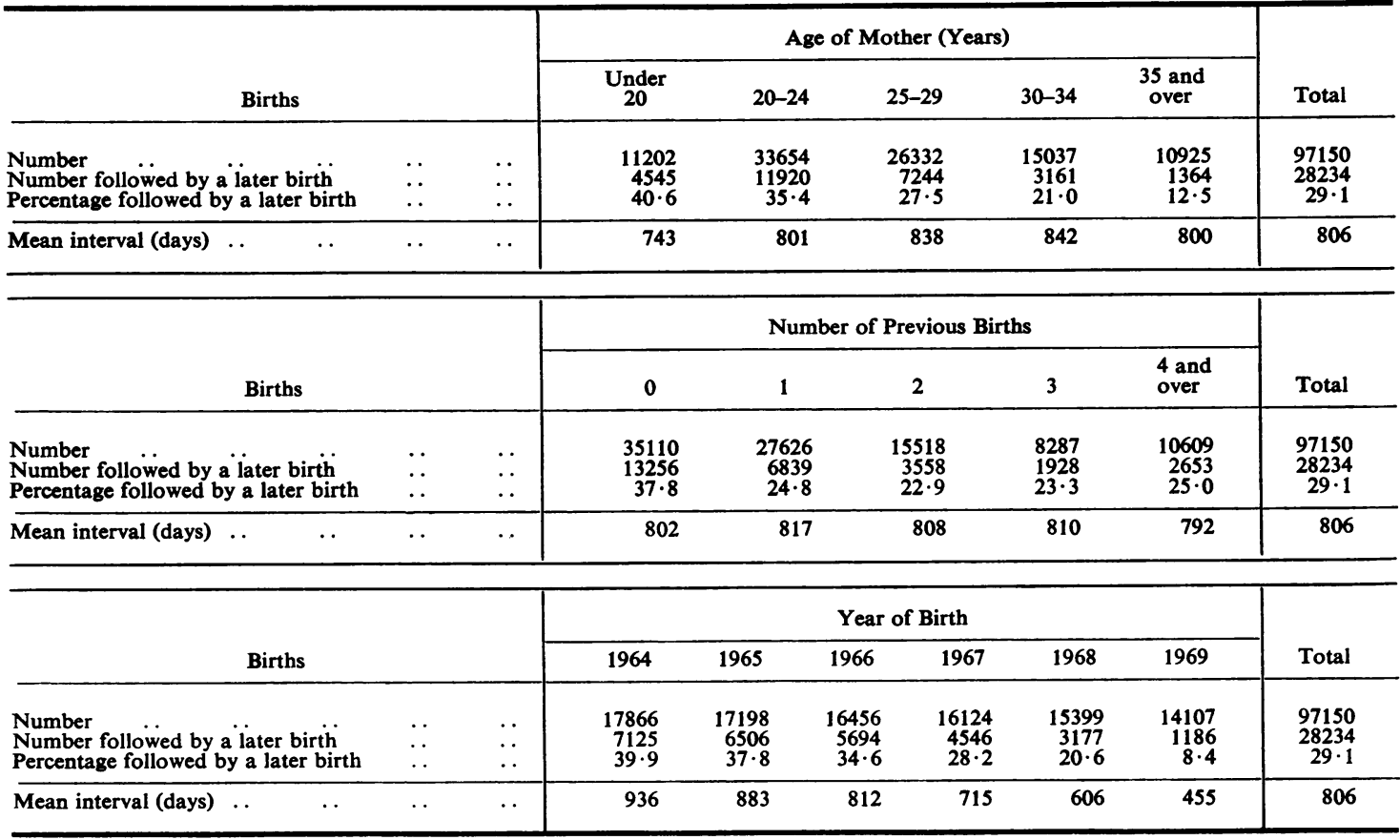

317 births for which the age of the mother or the number of previous births was not known have been excluded

pattern is revealed, the proportion ranging from $58 \%$ for mothers under 20 in 1964 with no previous births to less than $2 \%$ for mothers of 35 and over in 1969 with two previous births. Table I also shows that the interval between births is related to age and parity, and year of birth. The interval increases with increasing age up to 35 and then falls, and decreases steadily as the duration of follow-up decreases. The relation to parity is less regular.

It follows that simultaneous standardization for the three variables is a necessary preliminary to any comparison between mothers of malformed children and other mothers. This can be done if the total population of births is allocated according to maternal age (five groups), parity (five groups), and year of birth (six years). This grouping produces 150 cells. The proportion of mothers who had a subsequent birth and the mean interval from the index birth to the next following are calaculated for each cell. Expected values for any specified malformation group can then be derived by summation over the whole table taking account of the number of malformed births in each age/parity/year of birth cell. Comparison of the observed and expected values gives a measure of the relative reproductive performance of mothers after the malformed birth.

\section{RESULTS}

Since some malformations frequently result in death at or soon after birth it seemed desirable, before examining the effect of the birth of a malformed child on subsequent reproduction, to investigate whether a perinatal death or a death later in infancy influenced the parents' reproductive pattern. Results of this analysis indicate that both perinatal and later infant deaths are followed by an increased likelihood of a subsequent birth and that the interval before the next birth is shorter than usual (Table II). This suggests that parents who have been disappointed in the outcome of a pregnancy by stillbirth or death of the child tend to compensate for the loss. In view of this it is necessary in the analysis which follows to distinguish between malformations which resulted in stillbirth or death in infancy and those where the child survived the first year. It also seems advisable to distinguish between major malformations which threaten survival or seriously impair the quality of life and 
TABLE II

REPRODUCTIVE EXPERIENCE OF WOMEN FOLLOWING A PERINATAL DEATH (STILLBIRTH OR DEATH IN THE FIRST WEEK) AND A DEATH IN THE REST OF THE FIRST YEAR

\begin{tabular}{|c|c|c|c|c|c|c|c|}
\hline \multirow[b]{2}{*}{ Deaths } & \multirow[b]{2}{*}{ No. } & \multicolumn{3}{|c|}{ No. followed by a Subsequent Birth } & \multicolumn{3}{|c|}{ Mean Interval to Next Birth (Days) } \\
\hline & & Observed (O) & Expected $^{*}(\mathrm{E})$ & O/E & Observed (O) & Expected $*(E)$ & O/E \\
\hline $\begin{array}{l}\text { Perinatal } \\
\text { Infant after first week } . .\end{array}$ & $\begin{array}{r}2053 \\
698\end{array}$ & $\begin{array}{l}745(36 \cdot 3) \\
293(42 \cdot 0)\end{array}$ & $\begin{array}{l}589(28 \cdot 7) \\
211(30 \cdot 2)\end{array}$ & $\begin{array}{l}1 \cdot 26 \\
1 \cdot 39\end{array}$ & $\begin{array}{l}681 \\
691\end{array}$ & $\begin{array}{l}787 \\
801\end{array}$ & $\begin{array}{l}0.87 \\
0.86\end{array}$ \\
\hline Total & 2751 & $1038(37 \cdot 7)$ & $800(29 \cdot 1)$ & $1 \cdot 30$ & 684 & 791 & 0.86 \\
\hline
\end{tabular}

*Expected values are based on the experience of all mothers distributed by maternal age, parity, and year of index birth as the mothers of dead infants

Percentages are given in parentheses

TABLE III

REPRODUCTIVE EXPERIENCE OF WOMEN FOLLOWING THE BIRTH OF CHILDREN WITH MAJOR MALFORMATIONS RESULTING IN STILLBIRTH OR INFANT DEATH

\begin{tabular}{|c|c|c|c|c|c|c|c|}
\hline \multirow{2}{*}{$\begin{array}{l}\text { Site and } \\
\text { Type of Malformation }\end{array}$} & \multirow{2}{*}{$\begin{array}{l}\text { No. of } \\
\text { Cases }\end{array}$} & \multicolumn{3}{|c|}{ No. Followed by Another Birth } & \multicolumn{3}{|c|}{ Mean Interval to Next Birth (Days) } \\
\hline & & Observed (O) & Expected (E) & O/E & Observed (O) & Expected (E) & O/E \\
\hline \multirow{2}{*}{$\begin{array}{l}\text { Nervous system } \\
\text { Anencephalus .. } \\
\text { Spinabifida, encephalocele, } \\
\text { iniencephalus .. } \quad . . \\
\text { Hydrocephalus }\end{array}$} & 134 & 55 & $37 \cdot 15$ & $1 \cdot 48$ & 711 & 787 & 0.90 \\
\hline & $\begin{array}{r}102 \\
35\end{array}$ & $\begin{array}{l}35 \\
15\end{array}$ & $\begin{array}{r}29 \cdot 12 \\
9 \cdot 97\end{array}$ & $\begin{array}{l}1 \cdot 20 \\
1 \cdot 50\end{array}$ & $\begin{array}{l}680 \\
476\end{array}$ & $\begin{array}{l}797 \\
772\end{array}$ & $\begin{array}{l}0.85 \\
0.62\end{array}$ \\
\hline Heart and great vessels .. & 174 & 75 & $50 \cdot 54$ & $1 \cdot 48$ & 693 & 801 & 0.87 \\
\hline $\begin{array}{l}\text { Upper alimentary tract } \\
\text { Clefts of lip and palate } \\
\text { Tracheo-oesophageal fistula }\end{array}$ & $\begin{array}{l}14 \\
11\end{array}$ & $\begin{array}{l}6 \\
3\end{array}$ & $\left.\begin{array}{r}4 \cdot 73 \\
3 \cdot 27\end{array}\right\}$ & $1 \cdot 13$ & $\begin{array}{r}1000 \\
476\end{array}$ & $\left.\begin{array}{l}887 \\
931\end{array}\right\}$ & 0.92 \\
\hline $\begin{array}{l}\text { Lower alimentary tract } \\
\text { Anal atresia } \\
\text { Other intestinal obstruction } \\
\text { (excluding meconium ileus) }\end{array}$ & $\begin{array}{r}13 \\
7\end{array}$ & $\begin{array}{l}5 \\
2\end{array}$ & $\left.\begin{array}{r}3 \cdot 54 \\
2 \cdot 12\end{array}\right\}$ & $1 \cdot 24$ & $\begin{array}{l}428 \\
737\end{array}$ & $\left.\begin{array}{l}822 \\
463\end{array}\right\}$ & 0.72 \\
\hline $\begin{array}{l}\text { Genito-urinary tract } \\
\text { Renal agenesis } \\
\text { Other major defects }\end{array}$ & $\begin{array}{l}18 \\
16\end{array}$ & $\begin{array}{l}7 \\
7\end{array}$ & $\left.\begin{array}{l}4 \cdot 04 \\
4.98\end{array}\right\}$ & $1 \cdot 55$ & $\begin{array}{l}512 \\
657\end{array}$ & $664\}$ & $0 \cdot 82$ \\
\hline 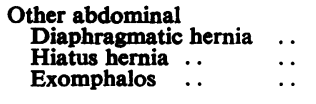 & $\begin{array}{l}17 \\
1 \\
13\end{array}$ & $\begin{array}{l}7 \\
0 \\
2\end{array}$ & $\left.\begin{array}{l}4 \cdot 93 \\
0 \cdot 31 \\
3 \cdot 16\end{array}\right\}$ & 1.07 & $\frac{553}{455}$ & $\left.\frac{734}{722}\right\}$ & 0.73 \\
\hline Down's disease ... & 40 & 12 & $8 \cdot 57$ & $1 \cdot 40$ & 692 & 841 & 0.82 \\
\hline Other .. & 40 & 14 & $12 \cdot 32$ & $1 \cdot 14$ & 593 & 746 & 0.79 \\
\hline Total ... & 635 & 245 & $178 \cdot 75$ & $1 \cdot 37$ & 664 & 788 & 0.84 \\
\hline
\end{tabular}

minor malformations which are easily treated or require no treatment and which result in little or no disability.

There were 635 infants with major malformations who were born dead or died before their first birthday (Table III). Of these, 245 were followed by another birth within the period of the study. The number 'expected', based on the experience of all mothers of similar age and parity was 179 and the ratio of observed to expected was $1 \cdot 37$. The mean interval between the birth of the malformed child and the next birth was 664 days. The expected mean interval was 788 days giving an observed to expected ratio of 0.84 . These ratios closely resemble those shown in Table II based on stillbirths and infant deaths from all causes. This suggests that if the child died, the fact that it was malformed did not deter parents from further reproduction and they tended to hasten the next pregnancy as if the dead child had not been malformed.

Table III also shows the malformations divided according to site and type. Infants with two or more malformations have been assigned to the more serious category. For example, cases of anencephalus with spina bifida have been allocated to anencephalus, and renal agenesis with diaphragmatic hernia to renal agenesis. All cases of Down's disease have been included under that heading even if cardiac defects or other malformations were present. When divided in this way some categories contain 
very small numbers. Nevertheless they showed considerable consistency; for every group there were more subsequent births than expected and the mean interval from the malformed birth to the next was shorter than usual. In the case of malformations of the nervous system and of the heart numbers are large enough to establish these points with some confidence.

Infants with major malformations who survived the first year numbered 656 of whom 165 had been followed by another birth by the end of the study. The number expected was 180 giving an observed to expected ratio of 0.92 . (Table IV). The mean interval from the malformed birth to the next was 863 days. The expected mean interval was 829 days and the ratio of observed to expected was 1.04. This result suggests that the continued presence in the home of an infant with a major malformation is a slight deterrent to further reproduction by the parents but the effect is small and cannot be regarded as established beyond doubt in this series. The individual groups of malformations can be viewed with even less confidence but there is a suggestion that spina bifida has a slightly greater deterrent effect than the other types.

There were 848 infants with minor malformations who survived the first year. The number followed by another birth (244) was very close to that expected (248) and the mean interval between the index birth and the next was not very different from that expected (Table V). It appears that minor malformations which carry no risk of death or serious disabliity do not lead to any modification of the parents' reproductive behaviour.

There were 30 infants with minor malformations who died from causes unconnected with the malformation. Eleven were followed by another birth (expected $10 \cdot 1$ ) and the mean interval was 930 days (expected 708 days). In view of the small numbers little importance can be attached to this result.

\section{Discussion}

The results of this investigation suggest that the birth of a severely malformed child acts as a slight deterrent to further reproduction if the child survives. This is perhaps hardly surprising in view of the exacting nature of the task of caring for children with these defects and the anxiety of parents regarding the outcome. On the other hand if the child is stillborn or dies early in life the parents tend to compensate for the loss in the same way that they do when a non-malformed child dies. This result was somewhat unexpected since it was $\varrho$ thought that parents of children with certain types? of malformation, particularly neural tube defects would have been told of the increased risk to subsequent children. In view of this it seemed worth ôे

TABLE IV

REPRODUCTIVE EXPERIENCE OF WOMEN FOLLOWING THE BIRTH OF CHILDREN WITH MAJOR MALFORMATIONS WHO SURVIVED THE FIRST YEAR

\begin{tabular}{|c|c|c|c|c|c|c|c|c|}
\hline \multirow{2}{*}{\multicolumn{2}{|c|}{$\begin{array}{c}\text { Site and } \\
\text { Type of Malformation }\end{array}$}} & \multirow{2}{*}{$\begin{array}{c}\text { No. of } \\
\text { Cases }\end{array}$} & \multicolumn{3}{|c|}{ No. Followed by Another Birth } & \multicolumn{3}{|c|}{ Mean Interval to Next Birth (Days) } \\
\hline & & & Observed (O) & Expected (E) & $\mathbf{O} / \mathbf{E}$ & Observed (O) & Expected (E) & $\mathbf{O} / \mathbf{E}$ \\
\hline \multicolumn{2}{|c|}{$\begin{array}{l}\text { Nervous system } \\
\text { Spina bifida, encephalocele, } \\
\text { iniencephalus .. } \\
\text { Hydrocephalus }\end{array}$} & $\begin{array}{r}107 \\
30\end{array}$ & $\begin{array}{l}26 \\
11\end{array}$ & $\begin{array}{r}31 \cdot 71 \\
9 \cdot 57\end{array}$ & $\begin{array}{l}0 \cdot 82 \\
1 \cdot 15\end{array}$ & $\begin{array}{l}866 \\
859\end{array}$ & $\begin{array}{l}814 \\
854\end{array}$ & $\begin{array}{l}1 \cdot 06 \\
1 \cdot 01\end{array}$ \\
\hline \multicolumn{2}{|l|}{ Heart and great vessels } & 125 & 31 & $34 \cdot 88$ & 0.89 & 787 & 833 & 0.94 \\
\hline \multicolumn{2}{|c|}{$\begin{array}{l}\text { Upper alimentary tract } \\
\text { Clefts of lip and palate ... } \\
\text { Tracheo-oesophageal fistula }\end{array}$} & $\begin{array}{r}133 \\
12\end{array}$ & $\begin{array}{r}34 \\
3\end{array}$ & $\begin{array}{r}35 \cdot 42 \\
3 \cdot 07\end{array}$ & 0.96 & $\begin{array}{l}943 \\
971\end{array}$ & $\begin{array}{l}844 \\
840\end{array}$ & $1 \cdot 12$ \\
\hline \multicolumn{2}{|c|}{$\begin{array}{l}\text { Lower alimentary tract } \\
\text { Anal atresia . } \\
\text { Other intestinal obstruction }\end{array}$} & $\begin{array}{r}22 \\
8\end{array}$ & $\begin{array}{l}6 \\
3\end{array}$ & $\begin{array}{l}5 \cdot 91 \\
1 \cdot 17\end{array}$ & $1 \cdot 18$ & $\begin{array}{r}641 \\
1350\end{array}$ & $\begin{array}{l}811 \\
806\end{array}$ & $1 \cdot 08$ \\
\hline \multicolumn{2}{|l|}{ Genito-urinary tract } & 24 & 6 & $6 \cdot 38$ & 0.94 & 798 & 743 & $1 \cdot 07$ \\
\hline \multicolumn{2}{|l|}{$\begin{array}{l}\text { Other abdominal } \\
\text { Diaphragmatic hernia } \\
\text { Hiatus hernia .. } \\
\text { Exomphalos } \quad .\end{array}$} & $\begin{array}{l}1 \\
9 \\
5\end{array}$ & $\begin{array}{l}0 \\
2 \\
1\end{array}$ & $\left.\begin{array}{l}0 \cdot 05 \\
2 \cdot 46 \\
1 \cdot 22\end{array}\right\}$ & $0 \cdot 80$ & $\begin{array}{r}13 \overline{40} \\
898\end{array}$ & $\left.\begin{array}{l}\overline{902} \\
741\end{array}\right\}$ & $1 \cdot 41$ \\
\hline \multirow{2}{*}{$\begin{array}{l}\text { Down's disease .. } \\
\text { Limbs } \\
\text { Reduction deformities }\end{array}$} & . & 109 & 21 & $23 \cdot 53$ & 0.89 & 791 & 827 & 0.96 \\
\hline & - & 30 & 10 & $10 \cdot 15$ & 0.99 & 880 & 874 & $1 \cdot 01$ \\
\hline Other .. & $\cdots$ & 41 & 11 & $13 \cdot 83$ & 0.80 & 844 & 807 & $1 \cdot 05$ \\
\hline Total $\ldots$ & $\cdots$ & 656 & 165 & $179 \cdot 89$ & 0.92 & 863 & 829 & $1 \cdot 04$ \\
\hline
\end{tabular}


TABLE V

REPRODUCTIVE EXPERIENCE OF WOMEN FOLLOWING THE BIRTH OF CHILDREN WITH MINOR MALFORMATIONS WHO SURVIVED THE FIRST YEAR

\begin{tabular}{|c|c|c|c|c|c|c|c|c|c|}
\hline \multirow{2}{*}{\multicolumn{3}{|c|}{$\begin{array}{c}\text { Site and } \\
\text { Type of Malformation }\end{array}$}} & \multirow{2}{*}{$\begin{array}{l}\text { No. of } \\
\text { Cases }\end{array}$} & \multicolumn{3}{|c|}{ No. Followed by Another Birth } & \multicolumn{3}{|c|}{ Mean Interval to Next Birth } \\
\hline & & & & Observed (O) & Expected (E) & $\mathrm{O} / \mathrm{E}$ & Observed (O) & Expected (E) & $\mathbf{O} / \mathbf{E}$ \\
\hline \multicolumn{3}{|c|}{$\begin{array}{l}\text { Special senses } \\
\text { Eye . } \\
\text { Accessory auricle } \\
\text { Other ear } \quad .\end{array}$} & $\begin{array}{l}10 \\
40 \\
18\end{array}$ & $\begin{array}{l}2 \\
8 \\
5\end{array}$ & $\begin{array}{r}3 \cdot 40 \\
11 \cdot 47 \\
4 \cdot 55\end{array}$ & 0.77 & $\begin{array}{l}680 \\
963 \\
742\end{array}$ & $\left.\begin{array}{l}888 \\
760 \\
855\end{array}\right\}$ & $1 \cdot 05$ \\
\hline \multicolumn{3}{|c|}{$\begin{array}{ccc}\text { Genito-urinary tract } & \\
\text { Hypospadias } & \ldots & \ldots \\
\text { Other } & \ldots & \cdots\end{array}$} & $\begin{array}{l}75 \\
10\end{array}$ & $\begin{array}{r}25 \\
0\end{array}$ & $\left.\begin{array}{r}20 \cdot 84 \\
2 \cdot 19\end{array}\right\}$ & $1 \cdot 09$ & 802 & 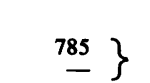 & $1 \cdot 02$ \\
\hline \multicolumn{3}{|c|}{$\begin{array}{lcc}\text { Limbs } & & \\
\text { Club foot } & \ldots & \ldots \\
\text { Polydactyly } & \ldots & \ldots \\
\text { Syndactyly } & \text {. } & \text {. } \\
\text { Congenital dislocation } & \text { of } \\
\text { hip } & \ldots & \ldots \\
\text { Other } & \ldots & \ldots\end{array}$} & $\begin{array}{r}327 \\
86 \\
79 \\
153 \\
13\end{array}$ & $\begin{array}{r}81 \\
24 \\
24 \\
59 \\
5\end{array}$ & $\begin{array}{r}91 \cdot 81 \\
25 \cdot 98 \\
23 \cdot 81 \\
48 \cdot 07 \\
4 \cdot 97\end{array}$ & 0.99 & $\begin{array}{l}680 \\
832 \\
862 \\
828 \\
649\end{array}$ & $\left.\begin{array}{l}782 \\
802 \\
825 \\
848 \\
727\end{array}\right\}$ & 0.95 \\
\hline Other $\ldots$ & . & $\cdots$ & 37 & 11 & $10 \cdot 45$ & $1 \cdot 05$ & 688 & 807 & 0.85 \\
\hline Total $\ldots$ & $\cdots$ & . & 848 & 244 & $247 \cdot 54$ & 0.99 & 771 & 806 & 0.96 \\
\hline
\end{tabular}

while to examine the data further to ascertain the malformation rate among children born after the index case.

It was shown in Tables III and IV that the series contained 1291 major malformations of which 410 were followed by a later birth. Eighteen of these later births had severe malformations and four had minor defects-a total incidence of 54 per 1000 which is more than double the rate for the series as a whole. Details are shown in Appendix I. There is a high recurrence rate for neural tube defects which were present in seven of the 142 infants born after a malformation of the central nervous system. This corresponds to a rate of 49 per 1000 which is more than ten times the rate for the whole series $(4 \cdot 2$ per 1000$)$. This is in accord with previous estimates of the recurrence rate of neural tube defects (Carter, Laurence, and David, 1968). It is not clear if parents received little information about the possibility of these malformations recurring in later pregnancies or whether they considered the risk to be within acceptable limits.

Although the other malformation groups showed less tendency to specific recurrence the malformation risk in subsequent pregnancies is certainly greater than normal. In particular there seems to be some evidence of an association within sibships between congenital heart disease and clefts of lip and palate, both types of defect being noted in each of four fraternities.

The malformation rate among infants following births with minor defects was even higher than the rate after major malformations, 18 of the 244 children being affected ( 74 per 1000$)$, but in only four was the second malformation regarded as severe. In ten instances the type of defect was the same as in the preceding birth (Appendix II). Although the risk of recurrence cannot be disregarded most of these minor malformations are amenable to treatment and produce little or no disability. It seems reasonable therefore that parents who have had an affected child should not be advised against having more children and it is clear from the results shown in Table $V$ that parents were not deterred by the occurrence of these malformations.

We are indebted to Dr E. L. M. Millar, CBE, and his staff in the City's Public Health Department for providing the basic data of this investigation, to Miss Ida Giles and Mrs Betty Mann for up-dating the information from hospital records, and to Mr Robert Lancashire for the computer linkage operation.

Requests for reprints: Dr R. G. Record, Department of Social Medicine, University of Birmingham Medical School, Birmingham 15.

\section{REFERENCES}

APLey, J., Barbour, R. F., and Westmacott, I. (1967). Impact of congenital heart disease on the family: preliminary report. Brit. med. J., 1, 103.

Boon, A. R. (1972). Tetralogy of Fallot-effect on the family. Brit. J. prev. soc. Med., 26, 263.

Carter, C. O., Laurence, K. M., and David, P. A. (1968). A family study of major central nervous system malformations in South Wales. J. med. Genet., 5, 81 .

hare, E. H., Laurence, K. M., Paynes, H., and RAWNSLEY, K. (1966). Spina bifida cystica and family stress. Brit. med. J., 2, 757. 
Hunt, G. M. (1973). Implications of the treatment of myelomeningocele for the child and his family. Lancet, 2, 1308.

Newcombe, H. B. (1965). The study of mutation and selection in human populations. Eugen. Rev., 57, 109.

and Rhynas, P. O. W. (1962). Child spacing following stillbirth and infant death. Eugen. Quart., 9, 25.

Polani, P. E. and Campbell, M. (1955). An aetiological study of congenital heart disease. Ann. hum. Genet., 19, 209.
Richards, I. D. G. and McIntosh, H. (1973). Spina bifida survivors and their parents: a study of problems and services. Devel. Med. Child Neurol., 15, 292.

SHEPS, M. C. (1965). An analysis of reproductive patterns in an American isolate. Pop. studies, 19, 65.

Timson, J. (1970). Social factors in the incidence of spina bifida and anencephaly. J. biosoc. Sci., 2, 81.

VoGel, H. P. and KNox, E. G. (1975). Reproductive patterns after stillbirth and early infant death. J. biosoc. Sci., 7, 103.

WALKeR, J. H., ThOMas, M., and RusSell, I. T. (1971). Spina bifida and the parents. Devel. Med. Child Neurol., 13, 462.

APPENDIX I

FREQUENCY OF MALFORMATIONS AMONG INFANTS FOLLOWING THE BIRTH OF CHILDREN WITH MAJOR MALFORMATIONS

\begin{tabular}{|c|c|c|c|c|c|c|c|c|c|}
\hline \multicolumn{6}{|c|}{ Site and Type of Malformations (Index Birth) } & $\begin{array}{l}\text { No. Followed by } \\
\text { Another Birth }\end{array}$ & No. Malformed & \multicolumn{2}{|c|}{ Type of Malformation } \\
\hline \multicolumn{3}{|c|}{$\begin{array}{l}\text { Nervous system } \\
\text { Anencephalus } \ldots \\
\text { Spina bifida, encephalocele } \\
\text { Hydrocephalus .. }\end{array}$} & $\begin{array}{l}\cdots \\
\cdots \\
\cdots\end{array}$ & $\begin{array}{l}\cdots \\
\cdots \\
\cdots\end{array}$ & $\begin{array}{l}\cdots \\
\cdots \\
\cdots\end{array}$ & $\begin{array}{l}55 \\
61 \\
26\end{array}$ & $\begin{array}{l}3 \\
3 \\
2\end{array}$ & $\begin{array}{l}\text { Anencephalus (1) } \\
\text { Anencephalus (2) } \\
\text { Hydrocephalus (1) }\end{array}$ & $\begin{array}{l}\text { Spina bifida (2) } \\
\text { Aortic anomaly (1) } \\
\text { Microcephalus (1) }\end{array}$ \\
\hline \multicolumn{2}{|c|}{ Heart and great vessels } & . & . & . & . & 106 & 7 & $\begin{array}{l}\text { Valve defect (1) } \\
\text { Cleft palate (1) } \\
\text { Hypospadias (1) } \\
\text { Polydactyly (1) }\end{array}$ & $\begin{array}{l}\text { Cleft lip (1) } \\
\text { Hermaphrodite (1) } \\
\text { Club foot (1) }\end{array}$ \\
\hline \multicolumn{2}{|c|}{$\begin{array}{l}\text { Alimentary tract } \\
\text { Clefts of lip and palate } \\
\text { Other } \ldots\end{array}$} & $\begin{array}{l}\cdots \\
\cdots\end{array}$ & $\begin{array}{l}\cdots \\
\cdots\end{array}$ & $\begin{array}{l}\cdots \\
\cdots\end{array}$ & $\begin{array}{l}\cdots \\
\cdots\end{array}$ & $\begin{array}{l}40 \\
22\end{array}$ & $\begin{array}{l}2 \\
0\end{array}$ & \multicolumn{2}{|c|}{ Congenital heart defect (2) } \\
\hline \multicolumn{2}{|c|}{ Genito-urinary tract } & . & . & . & . & 20 & 1 & \multicolumn{2}{|c|}{$\begin{array}{l}\text { Diaphragmatic hernia and renal } \\
\text { hypoplasia (1) }\end{array}$} \\
\hline Down's disease & . & $\cdots$ & $\cdots$ & . & $\cdots$ & 33 & 1 & \multirow{2}{*}{\multicolumn{2}{|c|}{$\begin{array}{l}\text { Craniorachischisis (1) } \\
\text { Transposition of great vessels (1) } \\
\text { Laurence-Moon-Biedl syndrome (1) } \\
\text { Club foot (1) }\end{array}$}} \\
\hline Other & $\cdots$ & $\cdots$ & $\cdots$ & . & . & 47 & 3 & & \\
\hline Total & $\ldots$ & $\cdots$ & . & . & $\cdots$ & 410 & 22 & & \\
\hline
\end{tabular}

APPENDIX II

FREQUENCY OF MALFORMATIONS AMONG INFANTS FOLLOWING THE BIRTH OF CHILDREN WITH MINOR MALFORMATIONS

\begin{tabular}{|c|c|c|c|c|c|c|}
\hline \multicolumn{4}{|c|}{ Type of Malformation (Index Birth) } & $\begin{array}{c}\text { No. Followed by } \\
\text { Another Birth }\end{array}$ & No. Malformed & Type of Malformation \\
\hline Defects of ext & ernal ear & $\cdots$ & $\cdots$ & 13 & 4 & $\begin{array}{l}\text { Polycystic kidney (1) Microtia and accessory auricle (1) } \\
\text { Hypoplasia of pinna (1) Club foot (1) }\end{array}$ \\
\hline Hypospadias & . & . & $\cdots$ & 25 & 2 & Cleft lip and palate (1) Hypospadias (1) \\
\hline Club foot & . & $\cdots$ & $\cdots$ & 81 & 6 & Down's disease (1) Hypospadias (1) Club foot (4) \\
\hline Polydactyly & . & . & . & 24 & 1 & Talipes (1) \\
\hline \multicolumn{3}{|c|}{ Congenital dislocation of hip } & . & 59 & 4 & Cri-du-chat syndrome (1) Congenital dislocation of hip (3) \\
\hline \multicolumn{2}{|c|}{ Other limb defects } & $\cdots$ & . & 29 & 1 & Megacolon and polydactyly (1) \\
\hline Other defects & $\cdots$ & $\cdots$ & $\cdots$ & 13 & 0 & \\
\hline Total & $\cdots$ & $\cdots$ & $\cdots$ & 244 & 18 & \\
\hline
\end{tabular}

